\title{
PRODUCTIVE CAPACITY OF CORN HYBRIDS FOR SILAGE
}

\author{
Radchenko Mykola ${ }^{1}$ \\ Zhyrnova Anna ${ }^{2}$
}

DOI: https://doi.org/10.30525/978-9934-571-89-3_109

Corn is one of the crops with diversified capacity for foodstuffs and feeding stuff production. It is also valuable raw product for processing industry. It has rather high productive potential, thus economic competitiveness comparing with most crops. Development of agriculture in Ukraine depends on sustainable production of food and feed grain. Corn takes leading position in this group according potential production. Technologies of corn growing are becoming more expensive because they include the improving of agrophysical characteristics, water and nutritive ground regimes, phytosanitary condition of sowings under the conditions of constant price increase. That is why a search of new ways of retrenchment by increasing corn yield is of primary importance $[1, \mathrm{p} .80]$.

However we should keep in mind that qualitative corn silage depends primarily on selection of the hybrid. Today there are a lot of selective companies at the market which propose to use hybrids of grain range for silage production. Thus, the hybrids of seed companies of the brands Monsanto, Pioner, Synhenta, Yevralis, KVS, Maisadur, Mais and others are offered. These hybrids are characterized by high plant height that facilitates to the yield of herbage but not always to the balance of nutrients content and high effectiveness of digestion. Moreover, recommended hybrids ensure quite high grain content in ensilage which also can digest not fully, that's why it needs additional plating or reducing to fragments.

There are also specialized corn hybrids for silage. They have low lignin content that facilitates to improving of ensilage digestion in animals stomachs. At the market the company LG proposes such hybrids. Besides today the company "LNZ Grup" proposes hybrids of Laefy type which are characterized by increasing of nutritive part of plant for animals due to the increasing of number of leaves above the spring from 10 to 13 pieces and mainly flour and glasslike starch in grain. The grain content in silage is also of great importance as it contains the most nutritive part of silage for animals. But not always a considerable amount of grain in ensilage indicates its high food value. That is why in this case consistency of grain endosperm makes a difference. Thus, grain with glasslike type of endosperm has

\footnotetext{
${ }^{1}$ Sumy National Agrarian University, Ukraine

2 Sumy National Agrarian University, Ukraine 
worse digesting comparing with flour type grain. Separation of this grain is better even by slicing and chewing by animals. Besides in the process of siloing such grain is easier to ferment [2].

Corn silage of the first class should contain $40-50 \%$ of ears in herbage and $25-35 \%$ of dry matter that is achieved by gathering plants in the phase of middle dough stage [3, p. 16; 4, p. 22].

The aim of the researches was optimization of height and development of corn for silage through selecting corn hybrids for the realization of its productivity potential.

The researches were conducted in educational and scientific production centre of Sumy National Agrarian University according to common methods during 2017-2018. Soil of researched field is typical thick loamy middle-humus black soil (chernozem) which is characterized by the following indices: humus content in plowed up layer (according to I.V. Tiuryn) $-4,0 \%$, reaction of soil solution is almost neutral (pH 6,6), the content of easy-hydrolysed nitrogen (according to I.V. Tiuryn) is 9,0 mg, mobile phosphorus and exchangeable potassium (according to $\mathrm{Ph}$. Chyrikov) is $14 \mathrm{mg}$ and $6,7 \mathrm{mg}$ accordingly for $100 \mathrm{mg}$ of soil.

The object of the researches was the following hybrids: DN Anshlah, Novyi, DN Bereka. The predecessor is winter wheat. The sowing was conducted by widerow method with spacing of $70 \mathrm{~cm}$ in optimal terms. General plot area was 50 square meters, record plot was 30 square meters, and research frequency was three-time. Plot placement is systematic. Mineral fertilizers $\left(\mathrm{N}_{116} \mathrm{P}_{24} \mathrm{~K}_{24}\right)$ were applied together with sowing.

During phenological observation in the beginning of growth and development phase corn plants took its occurrence not less than in $10 \%$ of plants, during the whole phase $-75 \%$. The dynamics of increasing ground weight was defined in the main growth and development phases by selecting 10 plants in typical places on the plots in two incompatible replications. The corn yield for silage was counted by the method of completed harvesting and weighing from every plot.

The reaction of corn plants to sort peculiarities was studied by the means of defining its indices of photosynthetic activity. The square of leaf area of sowing was quite changeable and depended on weather conditions during the years of the researches and researched factors.

At the beginning of vegetation period (7-8 leaves) the square of leaf apparatus varied in all plots from 2,4 to 3,0 thousands of square meters per ha on the average during the years of the researches.

In the phase of tasselling the biggest general square of assimilative area of one plant and sowing had the hybrid Novyi $\left(0,56 \mathrm{~m}^{2} ; 40,6\right.$ thousands $\mathrm{m}^{2}$ per ha), a little bit less square had the hybrid DN Anshlah $\left(0,53 \mathrm{~m}^{2} ; 36,6\right.$ thousands $\mathrm{m}^{2}$ per ha). The variant with hybrid DN Bereka the square was the smallest $-0,51 \mathrm{~m}^{2} ; 32,8$ thousands $\mathrm{m}^{2}$ per ha.

In the phase of milk-head ripeness the greatest square of assimilative area of one plant and sowing had the hybrid Novyi $\left(0,61 \mathrm{~m}^{2} ; 44,2\right.$ thousands $\mathrm{m}^{2}$ per ha), a little bit less square had the hybrid DN Anshlah $100\left(0,57 \mathrm{~m}^{2} ; 39,3\right.$ thousands $\mathrm{m}^{2}$ per ha). 
The variant with hybrid DN Bereka the square was the smallest $-0,54 \mathrm{~m}^{2}$; 34,8 thousands $\mathrm{m}^{2}$ per ha.

The weight of one plant in hybrids which were studied during vegetative period of corn was 446-754 g. Thus, the largest weight of corn plant was recorded in the phase of milk-head ripeness. Hybrid Novyi had the greatest plant weight $-752 \mathrm{~g}$ that is more on 3,9\% (29 g) than in hybrid DN Anshlah and on 6,3\% (47 g) than in hybrid DN Bereka.

The final target of corn growing for silage is to get the most high-quality yield. Yield forming and accumulation of economically valuable part in it is an important result of complex biochemical and physiological processes. The plant shows its all capacities under optimal environmental conditions which depend on certain soil and climatic conditions of a year and sort specific features. The data we got which characterize the value of corn yield for silage completely confirm the thesis above (Fig. 1).

The diagram information shows that yield capacity of hybrids of different ripeness was 45,5-54,5 ton per ha on the average. The maximal yield during the period of researches on the average formed the hybrid Novyi - 54,4 ton per ha. Hybrids DN Anshlah and DN Bereka had this index at the level of 50,0 and 45,5 ton per ha respectively (Figure 1).

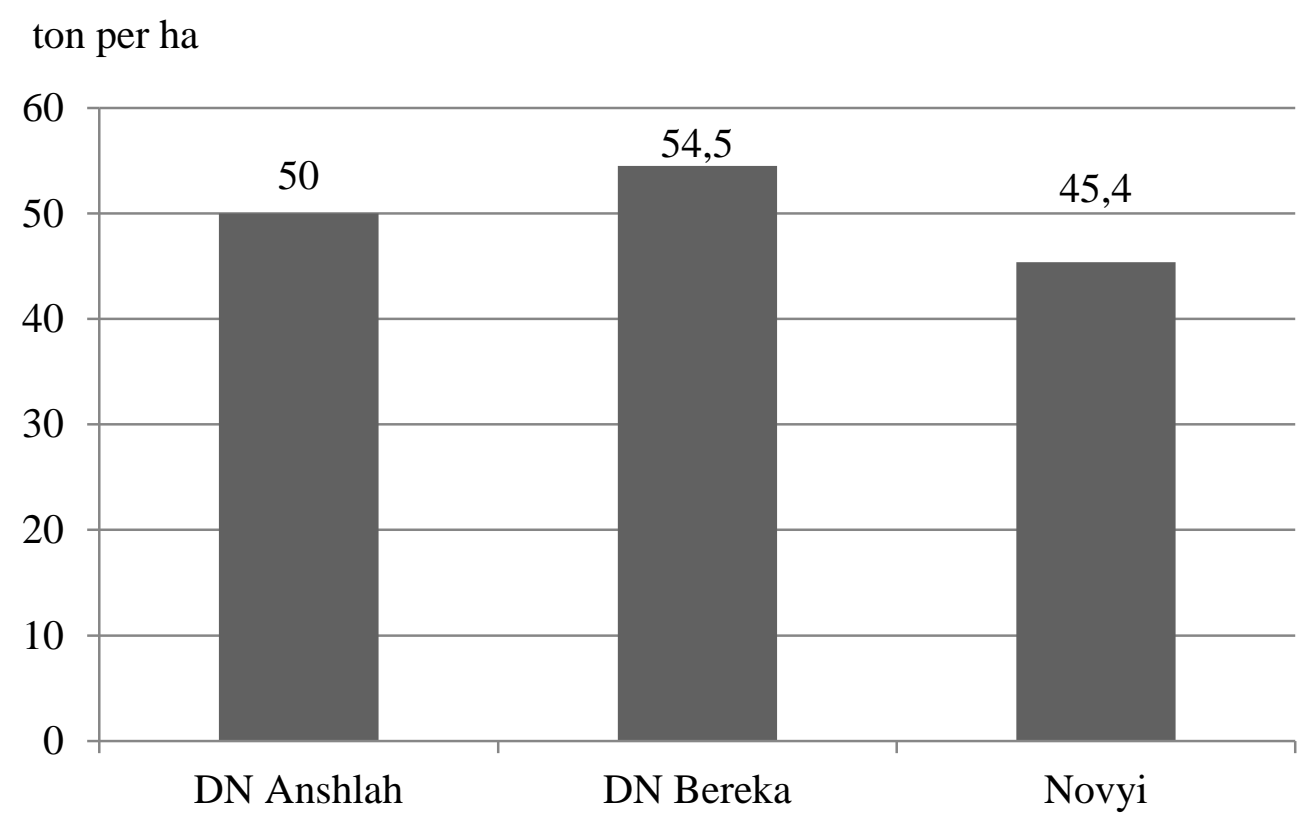

\section{Figure 1. Yield capacity of corn for silage depending on sort characteristics (mean value for 2017-2018), ton per ha}

The best conditions for formation of corn yield capacity for silage were in the variant with hybrid Novyi. This hybrid had the maximal yield of 54,5 ton per ha, assimilative area of one plant and sowing of $0,61 \mathrm{~m}^{2} ; 44,2$ thousand of square meters per ha and plant weight of $752 \mathrm{~g}$. 


\section{References:}

1. Maljarchuk A., Maljarchuk V. (2018). Kukurudza v sivozminakh na zroshuvaljnykh zemljakh [Corn in crop rotations on irrigated land]. Aghrobiznes sjoghodni, no. 7, pp. 80-82.

2. LNZ GROUP (2019). Vyroshhuvannja kukurudzy na sylos [Cultivation of corn for silage]. Retrieved from: https://www.lnz.com.ua/news/virosuvanna-kukurudzi-na-silos (accessed 2 March 2019).

3. Jefremova Z. S. (2005). Ghibrydy kukurudzy riznykh ghrup styghlosti [Corn hybrids of different ripening groups]. Kukurudza i sorgho, no. 5, pp. 16-18.

4. Lypovyj V. Gh., Lekhman V. A., Telefus V. A. Kukurudza riznykh ghrup styghlosti v sylosnomu konvejeri centraljnogho Lisostepu Ukrajiny [Corn of different ripening groups in silage chain of central forest steppe of Ukraine]. Kormy i kormovyrobnyctvo. Kyiv, no. 50, pp. 22-24. 